\title{
Laryngeal Papillary Squamous Cell
} Carcinoma

National Cancer Institute

\section{Source}

National Cancer Institute. Laryngeal Papillary Squamous Cell Carcinoma. NCI Thesaurus.

Code C54335.

A variant of squamous cell carcinoma that arises from the larynx. It is characterized by an exophytic and papillary growth usually in the suprag lottic area. The prognosis is favorable. 